\title{
Fields, Karen E.; Fields, Barbara J. \\ Racecraft: \\ the soul of inequality in American Life
}

Wanderson da Silva Chaves*

London and New York: Verso, 2012. 302p.

Karen and Barbara Fields are sisters and according to US racial convention - the principal object of analysis of this book, its openly iconoclastic ending, and the indignation of the authors -, are 'Afro-Americans' by definition. However, in this book they do not intend to dispute the use of other words in racial and original terminologies. Much to the contrary, the prefer to leave clear that as an intellectual project, rather than the freedom of choice between typologies, they defend the uprooting of the ideology of the 'social construction of race' (racecraft) from political discourse and social proposals. In an analysis which intends to illuminate how this ideology has updated and kept itself contemporary since the American Revolution, the authors emphatically seek to demonstrate what they consider to be at the same time an irrationality, an intellectual fraud, a historiographic evasion, a political crime, and an ethical problem.

From a centenarian family in South Carolina, based in Charleston - a city emblematic in Southern memory thanks to the importance of illustrious citizens in the Confederacy and the defense of slavery -, they problematized their intellectual apprenticeships and family memories to show that the manipulation of racial classification has strategic and ethical limits. Heirs of a now practically defunct tradition, anti-racism as a program with roots in the New Left in an age of liberal agendas and multi-culturalisms, they talk from within this tradition which reached them in the 1960s in the long history of struggles and civil disobedience against $\operatorname{Jim~Crow}^{1}$ and the racism reproduced in the ideology of the 'social construction of race.'

\footnotetext{
* Post-Doctoral Researcher. Universidade de São Paulo (USP), Departamento de História. Av. Professor Lineu Prestes, 338, Cidade Universitária. 05508-000 São Paulo - SP - Brasil. wanderson_schaves@ yahoo.com.br
} 
Published by Verso - a part of New Left Books, famous for publishing the New Left Review in the 1960 -, the books consists of ten chapters, with both new and republished texts, corresponding to an intellectual trajectory which began in the 1980s in the investigation of the popular forms of racial ideologies and in the 2000s reached their production in the academic universe. Karen, a sociologist and Africanist, currently based in Duke University, studies religion and was responsible for the new English translation (1995) of Émile Durkheim's classic The elementary forms of religious life. Barbara, a historian in Columbia University, has received awards for various works on US history and slavery, including Slavery and freedom on the Middle Ground: Maryland during the Nineteenth Century (1985); The destruction of slavery (1985); Slaves no more: three essays on emancipation and the Civil War (1992), and also coauthored Free at last: a documentary History of slavery, freedom, and the Civil War (1992).

Against the expectations and intentions of Barbara J. Fields, however, none of her works became as influential as her 1982 essay, Ideology and Race in American History. Since then she has fought against the fame of this text and the assessment that it offers support to visions of US history as a trajectory of intermixing and the construction of distinct arrangements of 'racial relations.' Racecraft, it can be said, is her most recent attempt to explain, to the exponents these readings, that studying Jim Crow does not correspond to accepting its grounding in the truism of the 'social construction of race' as an analytical assumption. The books demolishes the argument that 'race' is always a predicate of racism, and that historiography, as opposed to anachronism, has to take into account that race and racism belong to different modalities of 'social construction.'

What the Fields sisters frequently propose is the analysis of the common place of 'race' as something 'socially constructed,' resulting from the ideological productivity of racism. Leaving it clear that they do not mean by ideologies ideas such as doctrine, dogma, propaganda, a set of activities or beliefs, but rather "a descriptive vocabulary of daily life, through which people establish the meaning of the social reality in which they live and the materiality of which they create and recreate each day" (p.134), they invent the manner to operate this narrative, which defines the social ties in the human, social, and political unities of their readings of US history. Racism exists as an activity 
with a dual standard - in sociability, social stratification, relationships, and the perception of otherness -, in which subjects are given the attributes of objects. The action of the racist (those who recognize in the notion of 'race' a principle of reality) is transformed in this act into a racial attribute. The dynamics of the 'social construction of race' is structured by this fundamental habit. Its principal ideological operation, the transformation of predicates into objects of action, is surrounded by a fundamental procedure, that of obsessive classification and results, according to the authors, in two important results: it makes human relations 'racial relations' and distinguishes racism (when seen as a problem) from other forms of inequality.

For them this evasion of racism transformed into race has been central in the history of the United States since the War of Independence, and supported the consolidation of the anomalous position of slaves and later 'AfroAmerican' workers in a constitutional and actively democratic society, so as to sanction, with the veto of racism, pressures for alterations in this position. According to them the predominant approach in US historiography, by registering this experiences in the list of 'minorities' - a racial euphemism- constructed a characteristic narrative which sought (and still finds) support in four principal positions:

a) In the limitation of the South and the life of blacks, in the experiences of subordination, division, and racial familiarity;

b) In disconsidering slavery as an important dynamic in the other regions in the country and in the denial that there is a legacy of slavery shared by Americans;

c) In the analytical reduction through the 'segregation-integration' opposition of the complex universe of strategies of social ordering produced and lived in the United States;

d) In the denial of the any legitimacy to political agendas which express resentment and class projects, especially those raised by 'whites,' supposedly on the other side of the 'color line.'

The blind note of this historic narrative is, according to the authors, the intention to prove that segregation, a mark of US life, created what the South (but not just) knew as Jim Crow. For them, "slavery was a system of expropriating labor and not the administration of racial relations" (p.161), explaining that racism, unlike what is sustained, invented the separation of 'racial 
groups,' and not the contrary. In the proposed dating the formation of this racial ideology corresponded to the revolutionary project in defense of the liberties of free men, and updated itself as a prop of slavery and in a new turn of the screw in the establishment of the political and intellectual sphere of the permanent axis of the conversion of class resentments into racial ones, while the real dilemma of the United States is, they conclude, that it has multiple class resentments, but no language to express them.

For the Fields sisters, those who treat descendants of Africans or others ancestralities as a race - now less organizations such as the KKK than the academic discourse of 'identities' or 'agency' - carry out an act of exclusion from history and politics. With this impulse the preeminence of race in the public language about inequalities in the United States reinforces another US phenomenon, perhaps a more important one: the refusal to accept the problematic of class as a legitimate presence in the public sphere, turning groups whose exclusion is intended into 'races.'

The position of the authors towards the importance of racial quotas in social policy agendas follows the same evaluation: they are incapable of sustaining any sense of justice which does not represent a concession to the prestige of race. 'Racial tolerance,' the corollary of this agenda of 'inclusion,' is equally decried. Similar to what Richard Sennett argued in Respect in a world of inequality (2004), they see it as being useless to democracy: since it is not directed at the inequalities and exclusion which plaque US social life and politics, tolerance serves to divide society between those who allege respect as a right and those who solicit tolerance as an expression of good will.

In the middle of expectations that the presidency of Obama and the reform of US census categories are ushering in a 'post-racial' society, what Karen and Barbara Fields note is the renewed credibility of science and racial folklore in the inscription of popular notions and the old metaphors of blood (relationship and descent) in genetic and genome science, and from them its contraband into History and Ethnology. We can watch, in the fascination for everything which seems to designate itself as multi-racial/multicultural, the updating of the twentieth century debate about 'varieties of mixing' (miscegenation) - such as hybridization and even polygenia- and the intrusion of popular and erudite racist notions, renewed forms of the affirmation of 'racial purity.' 
For people who see the "concept of race as belonging to the same category of geo-centrism and witchcraft" (p.100), the fundamental work is the uprooting of the enormous terminological productivity and the potential for the social ordering of racism with its legacy of irrationality. This activity of release from the 'superstition' of racism, this bond of the past, they believe, has the potential to stimulate the imagination of new political lineages.

\section{NOTE}

${ }^{1} \mathrm{Jim}$ Crow is used to designate all the measures aimed at segregation and racial subordination in the United States since, approximately, the 1870s. The term began to circulate in the country in the 1830s, in theater sketches in which white men in blackface satirized slaves a as degraded and bestial creatures. After the 1840s the term came to be associated with legal and customary measures aimed at establishing social places and the form of treatment to black population had to give to the white. Jim Crow was consolidated as a political and legal category after the so-called Southern Reconstruction period (1865-1877).

Review received on 22 January 2013. Approved on 7 May 2013. 